\title{
Editors' Introduction to the Roundtable on Intellectual Freedom, Vigilantism, and Censorship in India
}

In this issue we carry a roundtable on intellectual freedom, vigilantism, and censorship in India consisting of four contributions (Vinay Lal, Romila Thapar, Deepak Sarma, and Aarti Sethi and Shuddhabrata Sengupta). The provocation that first led to a discussion of a roundtable like the one appearing in this issue occurred in 2011, when the University of Delhi removed A. K. Ramanujan's essay, “Three Hundred Ramayanas: Five Examples and Three Thoughts on Translation,” from its B.A. History (Honors) course in response to pressure from the Akhil Bharatiya Vidyarthi Parishad ("All India Student Council”), the student wing of the Bharatiya Janata Party ("Indian People's Party"). ${ }^{1}$ Yet a more recent and similar event, far more publicized internationally than the Ramanujan case, which each of the essays in this roundtable addresses is the pulping of Wendy Doniger's book, The Hindus: An Alternative History (2009), by its publisher Penguin India, who capitulated to pressure from an organization called the Shiksha Bachao Andolan Samiti (SBAS, "Save Education Movement Committee"). ${ }^{2}$ Penguin India's decision came after roughly four years in court dealing with a lawsuit filed by SBAS spokesman, Dinanath Batra, whose complaint cited a violation of Section 295a of the Indian Penal Code. Section 295a pertains to "Deliberate and malicious acts, intended to outrage religious feelings or any class by insulting its religion or religious beliefs," and reads thusly:

Deliberate and malicious acts, intended to outrage religious feelings or any class by insulting its religion or religious beliefs. Whoever, with deliberate and malicious intention of outraging the religious feelings of any class of citizens of India, by words, either spoken or written, or by signs or by visible representations or otherwise, insults or attempts to insult the religion or the religious beliefs of that class, shall be punished with imprisonment of either description for a term which may extend to three years, or with fine, or with both. ${ }^{3}$

Penguin India's capitulation is not a case of censorship by the state but rather an instance of self-censorship by the Indian branch of an international publishing firm under pressure from a non-government organization. Since the latter filed a suit against Penguin under Section 295a, a colonial-era (1927) law, the issues involved threaten intellectual freedom and amount to both vigilantism and censorship.

While the SBAS is an organization affiliated to the Hindu nationalist family of organizations (Sangh Parivar), with roots in the Rashtriya Swayamsevak Sangh ("National 
Volunteer Organization"), the issues of vigilantism and censorship taken up in this roundtable cut across political faultlines and have a long history going back to the Nehru era. Without going into a listing of early episodes, one can mention the harassment of artist M. F. Husain by Hindu nationalists and his self-exile in his last years (2006-11); the ban of Salman Rushdie's The Satanic Verses in 1988 by a Congress government; the decision by the University of Madras's Academic Council to remove two short stories by Pudumaipithan, Thunbakkeni and Ponnagaram, from its syllabus in February 2014; and many other instances of the curbing of intellectual freedom that go back to the 1950s and 1960s and the banning of Aubrey Menen's Rama Retold (1956), Stanley Wolpert's Nine Hours to Rama (1962) about Gandhi's assassination, and V. S. Naipaul's An Area of Darkness (1964). ${ }^{4}$

These events beg a number of important questions, which the following four essays both raise and attempt to answer. Among them, the authors speak to the forces behind the pattern of repeated accommodation of vigilante pressure to ban books, textbooks, plays, paintings, and so forth, on the grounds of hurt religious, nationalist or caste sentiments, as well as pre-emptive bans out of fear of public disturbances due to such hurt sentiments. We surmise that such a pattern, which cuts across party and religious boundaries, is related to the problem of building a nation and a state in an extremely heterogeneous country with a recent history of religious conflict in the aftermath of the Partition of 1947. The unstated nation-building and state-building strategy of Indian leadership since independence has been one of accommodation and inclusion, reflected in the constitution's secular and federal character, the abolition of caste discrimination and untouchability, explicit minority rights, and practices of political inclusion by the main political parties and governments that have so far dominated Indian politics. It also appears to be the case that part of this strategy and culture of accommodation allows for illiberal and authoritarian demands to proscribe academic and creative works that are held to hurt religious, nationalist and other group sentiments by self-appointed spokesmen of such groups who threaten public agitations and violence, sometimes leveling death threats, against the authors of such works (and the people and institutions that assisted the research of authors against whom objections are raised, as was the case in 2003 when the "Sambhaji Brigade" ransacked the Bhandarkar Oriental Research Institute [BORI] in Pune and attacked one of BORI's resident Sanskritists, Shrikant Bahulkar, where and with whom Jim Laine conducted research for his controversial book, Shivaji: Hindu King in Islamic India). ${ }^{5}$ The paradox here is this: while India has been largely successful in its building of a heterogeneous nation and a democratic state through accommodative policies, such policies also have at times accommodated illiberal demands and violated basic liberal-democratic norms of freedom of expression.

For 12 years India Review has been publishing innovative research on contemporary issues in India. We are thus delighted to add to current debates on India's intellectual freedom, vigilantism, and censorship the following four essays. They bring academic rigor, informed historical grounding, and varied perspectives to some of the 
vital issues currently coursing India's public commons on these issues. We hope the collection will stimulate further nuanced reflection on these pressing topics.

\section{-Eswaran Sridharan, Editor, and Anthony Cerulli, Managing Editor, India Review}

\section{NOTES}

1. A. K. Ramanujan, "Three Hundred Ramayanas: Five Examples and Three Thoughts on Translation," in Vinay Dharwadker, ed., The Collected Essays of A.K. Ramanujan (New Delhi: Oxford University Press, 2004), pp. 131-160.

2. Wendy Doniger, The Hindus: An Alternative History (New York: Penguin Books, 2009).

3. Indian Penal Code 295A. Accessible via http://www.vakilno1.com/bareacts/indianpenalcode/indian penalcode.html\#Section_295A_Deliberate_and_malicious_acts_intended_to_outrage_religious_feelings_or_ any_class_by_insulting_its_religion_or_religious_beliefs.

4. On Husain's self-imposed exile and the threats against him, see "MF Husain: Indian Artist Who Spends his Last Five Years in Self-Imposed Exile After Death Threats from Hindu Nationalists," The Independent, June 18, 2011; on the recent banning of Pudumaipithan's short stories, see "Pudumaipithan's 2 Short Stories Removed from Madras University Curriculum," The Hindu, February 24, 2014; on the banning of the books of Salman Rushdie, Aubrey Menen, Stanley Wolpert, V.S. Naipaul, and others, see "You Can't Read This Book," The Hindu, March 4, 2012.

5. On the reception of James Laine's book in India and its subsequent fallout, see "James Laine's Shivaji: Hindu King in Islamic India and the Attack on the Bhandarkar Oriental Research Institute," The Complete Review Quarterly: A Literary Saloon \& Site of Review Vol. 5, No. 1 (February 2004). Accessible via http://www. complete-review.com/quarterly/vol5/issue1/laine0.htm\#react. 